\title{
Xenoliths from the Letlhakane Kimberlite: Geochemistry and Implications for Mantle Processes.
}

Van Achterbergh, E. ', Griffin, W.L. ${ }^{1,2}$ and Stiefenhofer, J. ${ }^{3}$

1. GEMOC National Key Centre, School of Earth Sciences, Macquarie University, NSW 2109, Australia

2. CSIRO Exploration and Mining, P.O. Box 136, North Ryde, NSW 2113, Australia

3. Anglo American Research Laboratories (Pty) Ltd., P.O. Box 106, Crown Mines, 2025, South Africa

The geochemistry of mantle minerals has been the focus of many studies in the past decades, and as analytical techniques improve, so the database grows. Geochemists can now recognise some mantle processes from the major and trace element signatures of xenolith and concentrate minerals, eg. the high temperature asthenospheric melt interaction with mantle wallrock, recognised by increased $\mathrm{Ti}, \mathrm{Zr}$ and $Y$ in garnet (Griffin and Ryan, 1995). New data obtained for a set of samples from the Letlhakane kimberlite, using the Laser Ablation ICP-MS microprobe in the GEMOC National Key Centre, extends this database. In particular, we aim to add data to areas that were previously neglected, ie the effects of metasomatic processes on the geochemistry of rare earth elements (REE) and other trace elements in orthopyroxene and olivine (in the garnet stability field). The samples studied are a subset of those investigated by Stiefenhofer (1993), and consist of peridotite and metasomatised peridotite.

\section{Harzburgite vs Lherzolite}

Minerals from harzburgite and lherzolite xenoliths show several important differences in REE and other trace elements. Harzburgitic olivine and orthopyroxene are enriched in $\mathrm{Cr}$, relative to their lherzolitic counterparts. Olivine from lherzolite xenoliths is enriched in $\mathrm{Y}, \mathrm{Sc}$ and $\mathrm{Ga}$, and orthopyroxene in Mn when compared to harzburgitic phases. REE abundances in both minerals are low, but their concentrations are more often above the instrumental detection limits when the minerals are derived from a lherzolite paragenesis. The distribution of $\mathrm{Ca}$ in both minerals is temperature dependent, as noted by O'Reilly et al. (1997), and Norman (1998).

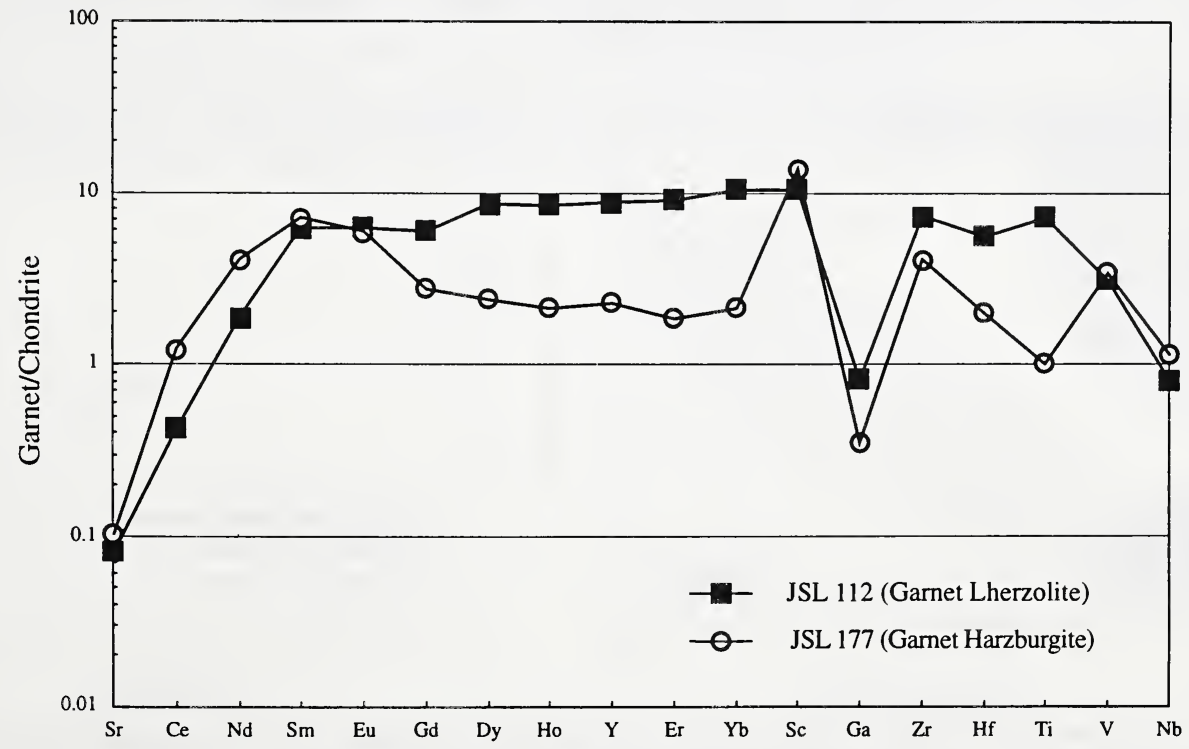

Figure 1: Examples of contrasting trace and rare earth element concentrations in lherzolitic and harzburgitic garnet. Note the relative depletion in heavy rare earth elements for harzburgitic garnet 
Positive correlations of $\mathrm{Ni}, \mathrm{Mn}$ and $\mathrm{Zn}$ with $\mathrm{Fe}$, and $\mathrm{Ni}$ and $\mathrm{Ni} / \mathrm{Co}$ with $\mathrm{Mg}$ number in olivine of the all the samples in the suite indicate the progressive extraction of a partial melt at some stage during their mantle residence (Norman, 1998).

Garnet trace element chemical composition is illustrated on chondrite normalised diagrams (Figure 1). In the harzburgite paragenesis, a sinuous REE pattern is defined by a "hump" for the MREE, and HREE depletion; this is a pattern recognised for harzburgitic garnet in xenoliths and diamond inclusions by other workers (Shimizu and Richardson, 1987; Nixon, 1987; Hoal et al., 1993; Nixon et al., 1994; Griffin et al., 1998). In lherzolite, garnet is rich in MREE and HREE, with a smooth, low positive slope on the diagram (Figure 1).

\section{Metasomatism}

At least three types of metasomatism are recognisable in these xenoliths. 1: The sinuous REE pattern in harzburgite garnet is interpreted to reflect cryptic metasomatism of depleted mantle, as suggested by Griffin et al. (1998). The absence of any other type of REE pattern for harzburgite garnet at Letlhakane is an indication of the extent of this metasomatism across the mantle volume sampled by the kimberlite. 2: The interaction of asthenospheric melt with upper mantle peridotite is recognised by sheared textures in xenoliths, high Ni temperatures in garnet, and enrichment in elements such as $\mathrm{Ti}, \mathrm{Y}$ and $\mathrm{Fe}$ in garnet and olivine. Trace element analysis reveals that all minerals from these samples are markedly enriched in the incompatible elements. 3: $\mathrm{K}$ metasomatism, of the type described by Erlank et al. (1987) is most common in these xenoliths, and was studied in more detail.

Petrographic investigation shows that garnet became unstable during the K-metasomatism, and broke down to form phlogopite, clinopyroxene and minor chromite. The progression of metasomatism is tracked by this reaction as the assemblage changes from garnet peridotite to garnet phlogopite peridotite, to phlogopite peridotite and finally to phlogopite rich wherlite. Analysis of the reacting garnet grains reveals no evidence for addition of REE or other trace elements, which shows that phlogopite-related metasomatism cannot always be recognised by garnet trace element geochemistry (Figure 2a; cf Griffin and Ryan, 1995). However, with increasing metasomatism, clinopyroxene becomes progressively enriched in REE and other trace elements. Modelling of the parent liquid responsible for the metasomatism (using published clinopyroxene-melt partition coefficients) shows that a fluid compositionally similar to a carbonatite melt might have been responsible for the changes observed. This is also consistent with the increase in $\mathrm{Ca}$ and Fe observed in the host rock, and the presence of calcite in the phlogopite cleavage planes.
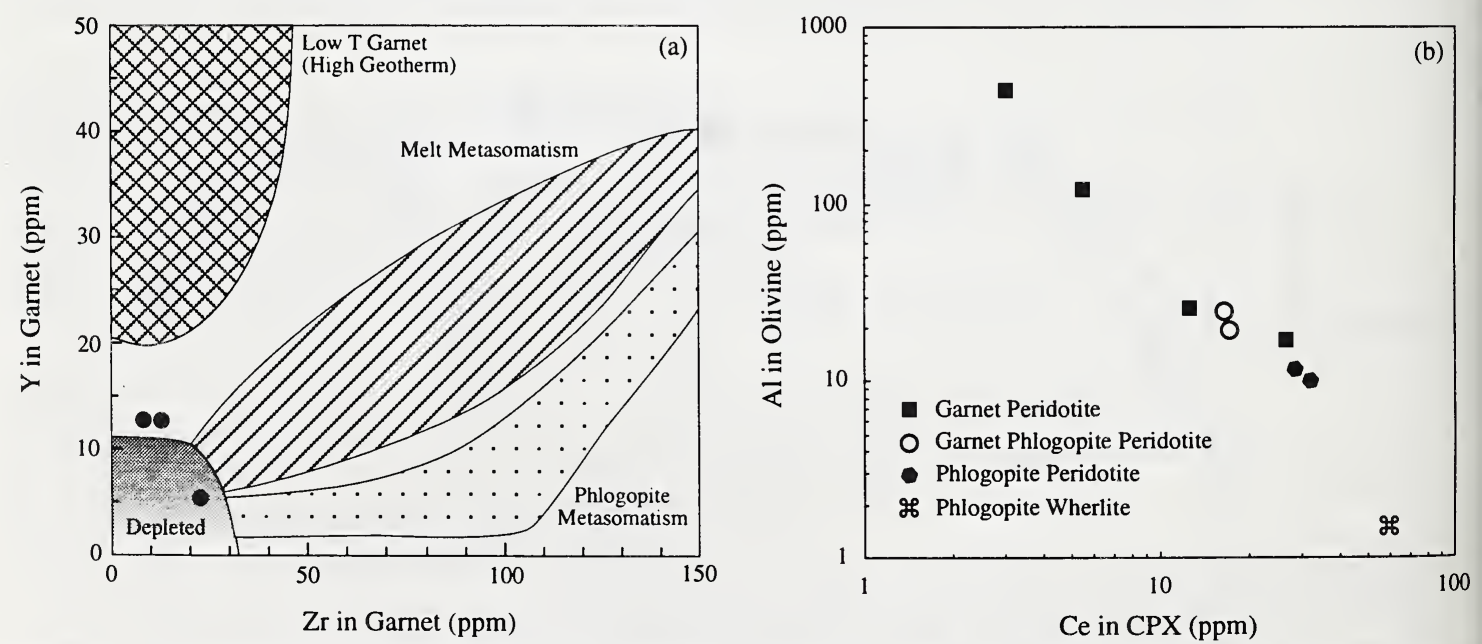

Figure 2: The influence of $\mathrm{K}$ metasomatism on peridotite minerals: (a) Average $\mathrm{Zr}$ and $\mathrm{Y}$ in garnet for three samples which contain abundant modal phlogopite show that garnet chemical composition is not always modified by metasomatism (diagram from Griffin and Ryan, 1995), and (b), Al depletion in olivine with the progress of metasomatism, as measured by Ce levels in coexisting cpx. 
The Ti content of olivine is usually temperature dependent (O'Reilly et al., 1997, Norman, 1998). However, in the metasomatised samples this does not hold true, as the olivine grains become anomalously enriched in $\mathrm{Ti}$ (165-203 ppm, vs 8.4-56 ppm in the unmetasomatised suite). Metasomatised orthopyroxene echo this $\mathrm{Ti}$ enrichment. Both orthopyroxene and clinopyroxene show reduced levels of $\mathrm{Co}$ and $\mathrm{Ni}$ in samples with advanced metasomatism.

A striking discovery is the anti-correlation of $\mathrm{Al}$ and $\mathrm{Ca}$ in the minerals of the metasomatised wallrock. All minerals, and in particular olivine, record a decrease in $\mathrm{Al}$ with increasing metasomatism, as measured by increasing levels of $\mathrm{Ce}$ in coexisting cpx (Fig. 2b). Major element analysis and careful point counting of the garnet $\rightarrow \mathrm{cpx}+$ phlogopite \pm chromite reaction psuedomorphs show that the products only account for half of the original $\mathrm{Al}$ that resided in the garnet. Erlank et al. (1987) also noted this Al decrease, but concluded that the metasomatism occurred in an environment already depleted in this element. However, the new data suggests that the metasomatism did in fact cause the depletion and that a strong chemical potential in Al existed towards the fluid source. It is this potential that drove the resorption and replacement of the garnet, and it contrasts strongly with other studies where garnet remains stable, or even grows (Griffin et al., 1998) during phlogopite-related metasomatism. This strongly suggests that the fluids responsible for metasomatism where garnet is stable and where garnet is unstable are distinctly different, and further work is needed to characterise these fluids.

\section{References Cited}

Erlank, A.J., Waters, F.G., Hawkesworth, C.J., Haggerty, S.E., Allsopp, H.L., Rickard, R.S., and Menzies, M (1987). In: Mantle Metasomatism. Menzies, M.A. and Hawkesworth, C.J. (eds), Academic Press, London, 472pp.

Griffin W.L. and Ryan C.G. (1995). J. Geochem. Exploration, 53, 311-337.

Griffin, W.L., Cousens, D.R. Ryan, C.G., Sie, S.H. and Suter, G.F. (1989). Contrib. Mineral. Petrol., 103, 199-202.

Griffin, W.L., Shee, S.H., Ryan, C.G., Win, T.T. and Wyatt, B.A. (1998). Contrib. Mineral. Petrol. (subm)

Hoal, K.E.O, Hoal, B.G., Erlank, A.J. and Shimizu, N. (1994). Earth. Plan Sci. Lett. 126, 303 - 313.

Nixon, P.H. (1987). In: Mantle Xenoliths. Nixon, P.H. (ed), Wiley and Sons, New York, 215 - 239.

Nixon, P.H., Griffin, W.L., Davies, G.R. and Condliffe, E. (1994). In: Kimberlites, Related Rocks and Mantle Xenoliths. Meyer, H.O.A. and Leonardos, O.H. (eds). CPRM Spec. Publ. 1A/93, 378 - 387.

Norman, M. D. (1998). Contrib. Mineral. Petrol. In press

O'Reilly S.Y., Chen, D. , Griffin, W.L. and Ryan C.G. (1997). Min Mag., 61, 257-269.

Ryan, C.G., Griffin, W.L. and Pearson, N.J. (1996). J. Geophys. Res. 101, 5611 - 5625.

Shimizu, N. and Richardson, S.H. (1987). Geochim. Cosmocim. Acta. 51, 755 - 758.

Stiefenhofer, J. (1993): The petrography, mineral chemistry and isotope geochemistry of a mantle xenolith suite from the Letlhakane DK 1 and DK 2 kimberlite pipes, Botswana. Unpubl. Ph.D. thesis, Rhodes University

Yaxley, G.M., Crawford, A.J. and Green D.H. (1991). Earth Plan Sci Lett., 107, 305-317. 